\title{
Climate change impact on soils: adaptation and mitigation
}

\section{Introduction}

The dependency of agriculture on climate is indicated by the fact that cultivation in mostly rain fed area of the total cropped area is dependent on uncertainties of monsoon. Climate change can impact directly on food security through food system stability. Agriculture is important for food security in two ways: it produces the food people eat; and it provides the primary source of livelihood for $36 \%$ of the world's total workforce. In the thickly populated countries of Asia and the Pacific, this share ranges from $40-50 \%$ and in sub-Saharan Africa, $67 \%$ of the working population still make their living from agriculture. Agriculture is considered both as a contributor to climate change and a victim as well. Agriculture is a contributor because it emits significant amount of greenhouse gases, and victim because climate change have considerable impacts on agricultural production. The fourth assessment report of Intergovernmental Panel on Climate Change (IPCC) made it clear that the global average temperature has increased by $0.74^{\circ} \mathrm{C}$ over the last 100 years and projected increase is about 1.8 to $4.0^{\circ} \mathrm{C}$ by 2100 . Climate change and agriculture are interrelated processes and global warming is projected to have significant impacts on agriculture by influencing through direct and indirect effects on crops, soils, livestock and pests. Apart from the probable decline in food production, nutritional quality of food may also be reduced raising a concern for nutritional security. Alarmed by the possible impact of the global climate change on the quality of life of human beings efforts are being made to develop strategies to mitigate its negative impacts. In light of these concerns, the impact of climate change on soils and its mitigation and adaptive strategies have been discussed.

\section{Climate change impacts on soils}

Climate change is global phenomena and occurring continuously since the earth came into existence. Climate change has become a major scientific and political issue during the last decade. There are well marked cold and hot cycles in the history of earth's climate, however, these changes have been observed relatively rapid in the last 150-200 years around the world. ${ }^{1}$ Soil seems to be more important for modern human societies than ever before to meet the global demands for food and fiber for increasing population from limited soil resources. Climate change is threatening food security globally. Countries like India are more vulnerable in view of the tropical climate and poor coping capacity of the small and marginal farmers. Climate change is projected to have significant impacts on agriculture through direct and indirect effects on crops, soils, livestock and pests. Though, climate change is a slow process involving relatively small changes in temperature and precipitation over long period of time, nevertheless these slow changes in climate influence the various soil processes particularly those related to soil fertility. The effects of climate change on soils are expected mainly through alteration in soil moisture conditions and increase in soil temperature and $\mathrm{CO}_{2}$ levels as a result of climate change. The global climate change is projected to have variable effects on soil processes and properties important for restoring soil fertility and productivity. The major effect
Volume 2 Issue 3 - 2017

\author{
Navneet Pareek \\ Department of Soil Science, GB Pant University of Agriculture \\ and Technology, India
}

Correspondence: Navneet Pareek, Department of Soil Science, GB Pant University of Agriculture and Technology, Pantnagar-26I 345, U. S. Nagar, Uttarakhand, India, Email pareeknav@gmail.com

Received: March 26, 2017 | Published: June 12, 2017

of climate change is expected through elevation in $\mathrm{CO}_{2}$ and increase in temperature.

\section{Soil formation}

Soil formation is controlled by numerous factors including climatic factors such as temperature and precipitation. These parameters of climate influence the soil formation directly by providing biomass and conditions for weathering. Main parameters of climate that directly influence on soil formation are sum of active temperatures and precipitation-evaporation ratio. They determine values of energy consumption for soil formation and water balances in soil, mechanism of organic-mineral interactions, transformation of organic and mineral substances and flows of soil solutions. Stable progressive climate warming lead to irreversible changes in mineral matrix of soils. Changes in external factors of soil formation (temperatures and precipitation) will lead to transformation of internal factors (energy, hydrological, biological). The climate change will increase energy of destruction of soil minerals resulting in simplification of mineral matrix due to accumulation of minerals tolerant to weathering. It will lead loss of soil function for fertility maintenance and greater dependence of on mineral fertilizers.

\section{Soil development}

Soil development is broadly controlled by three main factors i.e. climate, parent material and vegetation type. The effects of climate change on soil development are expected mainly through alteration in soil moisture conditions and increase in soil temperature and $\mathrm{CO}_{2}$ levels. Climate change will influence soil moisture levels by direct climatic effects (precipitation, temperature effects on evaporation), climate induced changes in vegetation, plant growth rates, rates of soil water extraction by plants and the effect of enhanced $\mathrm{CO}_{2}$ levels on plant transpiration. Changes in soil water fluxes may also feed back to the climate itself and even may contribute to drought conditions by decreasing available moisture, altering circulation patterns and increasing air temperatures. Among various factors controlling the process of soil development, climate plays a major role in weathering of rocks and minerals. The variables of climate change particularly temperature and rainfall dictates various stages of weathering of rocks 
and minerals (parent material) resulting in chemical and mineralogical changes in soil forming rocks. Water is very essential for chemical weathering to take place and hence, an increase in rainfall accelerates weathering. The same types of primary minerals give rise to different secondary minerals when the conditions of weathering differ. Thus similar rock types undergoing weathering in different climatic conditions could give rise to distinct soil profiles.

\section{Soil fertility and productivity}

The drivers of climate change such as moisture, temperature and $\mathrm{CO}_{2}$ are expected to have variable effects on various soil processes and properties having relevance in soil fertility and productivity. However, these effects of the climate change factors cannot be viewed separately, being one factor influence the other and resultant effect would be complex. Further, all these effects will be highly region specific, depending on the magnitude of the climate change, soil properties and climatic conditions. India is bestowed with 9 of the 12 soil orders that exist in world and 15 agro-climatic zones, with diverse seasons, crops and farming systems. Since climate change is a reality, it will have direct and indirect impacts on soil development processes and properties related to crop production influencing the livelihoods of millions of peoples in the country. The impact of climate change factors, specifically temperature, $\mathrm{CO}_{2}$ and rainfall on various soil properties is being discussed below to understand the relationship between climate change variables and various soil properties in order to evolve appropriate mitigation strategies (Table 1).

\section{Plant nutrient availability and acquisition}

Plant availability of nutrients in the soil is a function of soil chemical properties as well as location of the ion relative to the root surface and the length of the pathway the nutrient must travel in the soil to reach the root surface. Increases in air temperature and changes in precipitation have significant impacts on root zone temperature and moisture regimes. It is well known that soil moisture and temperature are primary determinants of nutrient availability and root growth and development and that carbon allocation to roots governs nutrient acquisition, it is reasonable to expect that process outcomes will be reflective of the changed climate. The nature and extent of the change in these two parameters will be site- and soils specific. It has been suggested that climate change impacts on nutrient use efficiency is be primarily affected through direct impacts on root surface area and influx rate. ${ }^{2}$

\section{Nutrient transformation in soil}

Plants accumulate nutrients from the soil solution pool, and nutrients must be in solution to be mobile in the soil. Biological transformation between organic and inorganic pools is strongly influenced by moisture and temperature, and thus, global climate change may strongly influence solution concentrations of $\mathrm{N}$ as well as $\mathrm{S}$ Pendall et al. ${ }^{3}$ suggests that increased $\mathrm{CO}_{2}$ may not exert a significant direct effect on $\mathrm{N}$ mineralization per se but associated warming can cause increased $\mathrm{N}$ mineralization, leading to increased solutionphase N. Rates of adsorption/ desorption reactions will accelerate with increased temperature, and changes in soil moisture may further modify reactions by altering the ionic strength of the soil solution.

\section{Soil carbon dynamics}

It is generally accepted that increases in $\mathrm{CO}_{2}$ concentration quantitatively and qualitatively alter the release of root derived compounds. Plants under elevated $\mathrm{CO}_{2}$ decrease their allocation of $\mathrm{N}$-rich metabolites and increase the allocation of $\mathrm{C}$ rich metabolites to root exudates. ${ }^{4}$ It results in an increase in microbial activity and consequently the $\mathrm{CO}_{2}$ production, which has is a potential negative effect on the accumulation of organic $\mathrm{C}$ in soils and thus on potential sequestration of soils. It has been observed that the priming effect as a result of the enhanced microbial activity in soil at elevated atmospheric $\mathrm{CO}_{2}$ concentration has a significant negative feedback on global change processes and will reduce the sequestration potential of soils. Several studies using $\mathrm{C}$ isotope tracers have demonstrated that the production of $\mathrm{CO}_{2}$ in the rhizosphere by roots and microorganisms is significantly stimulated by elevated $\mathrm{CO}_{2}$ plant growth conditions. The stimulation of $\mathrm{CO}_{2}$ respiration in the rhizosphere may be much higher than the enhancement of root biomass. Cheng et al. ${ }^{7}$ demonstrated that although plants produced only $15-26 \%$ more biomass under elevated $\mathrm{CO}_{2}$, rhizosphere respired $\mathrm{C}$ increased by $56-74 \%$ as compared to ambient $\mathrm{CO}_{2}$ treatments.

\section{Response to mycorrhizal association}

The effects of elevated atmospheric $\mathrm{CO}_{2}$ concentration on soil microbial community structure are often characterized by an increased mycorrhizal colonization due to the increased plant demand for nutrients, coupled with increased $\mathrm{C}$ assimilation rates $\mathrm{CO}_{2}$ enrichment should increase mycorrhizal biomass because plant demands for $\mathrm{N}$ and $\mathrm{P}$ will increase concurrently with $\mathrm{C}$ assimilation rates, and plants will allocate more hotosynthates belowground to the roots and mycorrhizal fungi to help satisfy this increased nutrient demand. Greater fine root mass and mycorrhizal infection promote enhanced $\mathrm{P}$ uptake in mycorrhizal plants grown under elevated $\mathrm{CO}_{2}$ concentrations. It seems reasonable to expect that at elevated $\mathrm{CO}_{2}$ levels, mycorrhizal biomass will increase as $\mathrm{C}$ becomes relatively less limiting and soil nutrients become more limiting to plant growth. ${ }^{5}$ However, information available in literature is not always consistent on this point.

\section{Soil biological activities}

The response of soil microorganisms to changes in plant production under elevated $\mathrm{CO}_{2}$ is highly variable due to very different patterns of plant $\mathrm{C}$ allocation in different plant-soil systems. Microbial biomass, gross $\mathrm{N}$ mineralization, microbial immobilization, and net $\mathrm{N}$ mineralization under elevated $\mathrm{CO} 2$ show a high degree of variability. However, rates of soil and microbial respiration are generally more rapid under elevated $\mathrm{CO}_{2}$, indicating that enhanced plant growth under elevated $\mathrm{CO}_{2}$ increases the amount of $\mathrm{C}$ entering the soil, thereby stimulating soil microbial activity. Soil microorganisms are often C-limited and therefore, increased $\mathrm{C}$ availability stimulates microbial growth and activity. It is generally assumed that the $\mathrm{CO}_{2}$ induced increases in soil $\mathrm{C}$ availability will increase fungal biomass more than bacterial biomass. It is because of increased concentrations of dissolved organic $\mathrm{C}$ in the rhizosphere and to increases in soil water dissolved organic N. Given the important roles played by fungi in organic matter degradation, nutrient cycling, plant nutrition, and soil aggregate formation, shifts in fungal communities might have a strong impact on soil functioning. Furthermore, lower $\mathrm{N}$ availability at elevated $\mathrm{CO}_{2}$ may, in part, explain these increases in fungi, as fungi tend to have a higher $\mathrm{C} / \mathrm{N}$ ratio than bacteria and so have a lower demand for nitrogen than bacteria have. ${ }^{6}$ Bacteria and fungi, the initial consumers of soil organic matter, are themselves 
substrates for a multitude of tiny predators and grazers, including protozoa, nematodes, and arthropods, which comprise the soil food web. Therefore, an increase in bacterial growth due to an increasing $\mathrm{C}$ allocation at elevated atmospheric $\mathrm{CO}_{2}$ levels may be followed by an increase in grazing, resulting in a higher turnover of the microbial biomass. Increased grazing thus results in faster recycling of nutrients from the microbial biomass, which would increase the flux of nutrients to the plant.

\section{Adaptation and mitigation strategies}

Agriculture can adapt to climate change by adopting farm management practices that minimize the adverse effects of increasing or decreasing rainfall and temperatures or other extreme weather conditions. Many management-level adaptation options are available to attenuate the effects of climate change on crop production, including zero tillage, retaining crop residues, extending fallows, increasing the diversity of production, altering amounts and timing of external inputs (fertilizers, water), as well as broader agronomic management strategies (e.g. altering planting density, row spacing, planting time; introducing new germplasm resistant to heat or drought stress). Agriculture can contribute to climate change mitigation through farm management practices that reduce greenhouse gas emissions (carbon dioxide, nitrous oxide, methane) and enhance soil carbon sequestration. Emissions of carbon dioxide can be reduced through reduced biomass burning and more efficient energy use. Emissions of methane can be reduced through improved farm management practices that include improved management of livestock waste and water in rice paddies. Nitrous oxide emissions can be reduced through improved management of $\mathrm{N}$ fertilizers including appropriate type, rate and method of application and soil management (avoidance of soil compaction).

Various farm management practices can enhance soil carbon stocks and encourage soil functional stability. Conservation agriculture technologies (minimum soil disturbance, cover crops and crop rotations including legumes), soil conservation measures (e.g. contour farming) and nutrient replenishment strategies can restore soil organic matter by providing a protective soil cover and an environment conducive to vigorous plant growth. In some cases, however, a change in the agricultural production system may be required. e.g. continuous cereal cropping being replaced by ley farming or by the introduction of agroforestry systems. The global soil carbon pool exceeds biomass pools by a factor of four or five, without taking into account that recent soil degradation has led to losses of between 30 percent and 75 percent of their antecedent soil organic carbon. Globally, therefore, a soil carbon increase offers great mitigation potential. Carbon sequestration refers to the storage of carbon in a stable solid form. It occurs through direct and indirect fixation of atmospheric $\mathrm{CO}_{2}$. Direct soil carbon sequestration occurs by inorganic chemical reactions that convert $\mathrm{CO}_{2}$ into soil inorganic carbon compounds such as calcium and magnesium carbonates. Direct plant carbon sequestration occurs as plants photosynthesize atmospheric $\mathrm{CO}_{2}$ into plant biomass. Subsequently, some of this plant biomass is indirectly sequestered as soil organic carbon (SOC) during decomposition processes. The amount of carbon sequestered at a site reflects the long-term balance between carbon uptake and release mechanisms. Many agronomic, forestry, and conservation practices, including best management practices, leads to a beneficial net gain in carbon fixation in soil.

Agro-ecosystems can play an important role in mitigating $\mathrm{CO}_{2}$ emissions through biotic $\mathrm{C}$ sequestration in soils and vegetation. Because of historic losses of $\mathrm{C}$ from soils, estimated to be 41 to 55 Gt, the soils now offer an opportunity for carbon storage. The carbon sequestration potential of a soil depends on climate, the type of vegetation it supports, the nature of parent material, the depth of solum, soil drainage, the edaphic environment, soil organic matter (SOM) content and its decomposability and land management practices. Improved management of agro-ecosystems can significantly enhance $\mathrm{C}$ sequestration in soils. Management practices or technologies that increase carbon input to the soil and reduce $\mathrm{C}$ loss or both lead to net carbon sequestration in soils (Table 1). Increased $\mathrm{C}$ input in agroecosystems can be achieved in a number of ways such as selection of high biomass producing crops, residue recycling or residue retention by lessened tillage intensity, application of organic materials (e.g. animal manure, compost, sludge, green manure etc.), adoption of agro forestry systems, intensification of agriculture through improved nutrient and water management practices, reducing summer or winter fallow, changing from monoculture to rotation cropping, and switching from annual crops to perennial vegetation. Soil carbon loss could be decreased by adopting conservation agriculture and minimizing soil disturbance, checking erosion through reduced tillage intensity, and using low quality organic inputs. Technological options that have been found to be efficient for soil $\mathrm{C}$ sequestration in Indian agro-ecosystems include integrated nutrient management and maturing, crop residue incorporation, mulch farming and/conservation agriculture, agro-forestry systems, grazing management, choice of cropping system and intensification of agriculture. Integrated nutrient management involving addition of organic manures/composts along with inorganic fertilizers results in improved soil aggregation. ${ }^{8}$

Table I Summary of expected effects of individual climate change variables on soil processes

Loss of soil organic matter

Reduction in labile pool of SOM

Increasing temperature

Reduction in moisture content

Increase in mineralization rate

Loss of soil structure

Increase in soil respiration rate

Increase in soil organic matter

Increase in water use efficiency

Increasing $\mathrm{CO}_{2}$ concentration

More availability of carbon to soil microorganisms

Accelerated nutrient cycling. 


$\begin{array}{ll} & \text { Increase in soil moisture or soil wetness } \\ & \text { Enhanced surface runoff and erosion } \\ & \text { Increase in soil organic matter } \\ & \text { Nutrient leaching } \\ \text { Increasing rainfall } & \text { Increased reduction of Fe and nitrates } \\ & \text { Increased volatilization loss of nitrogen } \\ & \text { Increase in productivity in arid regions } \\ & \text { Reduction in soil organic matter } \\ \text { Reduction in rainfall } & \text { Soil salinization } \\ & \text { Reduction in nutrient availability }\end{array}$

\section{Acknowledgements}

None.

\section{Conflict of interest}

The author declares no conflict of interest.

\section{References}

1. Fauchereau N, Trzaska M, Rouault M, et al. Rainfall variability and changes in Southern Africa during the $20^{\text {th }}$ century in the global warming context. Natural Hazards. 2003;29(2):139-154.

2. Brouder SM, Volenec JJ. Impact of climate change on crop nutrient and water use Efficiencies. Physiologia Plantarum. 2008;133(4):705-724.

3. Pendall E, Bridgham S, Hanson PJ, et al. Below-ground process responses to elevated $\mathrm{CO}_{2}$ and temperature: a discussion of observations, measurement methods, and models. New Phytol. 2004;162(2):311-322.

4. Tarnawski S, Aragno M. The influence of elevated $\mathrm{CO}_{2}$ on diversity, activity and biogeochemical function of rhizosphere and soil bacterial communities. In: Nösberger J, Long SP, et al. editors. Managed ecosystems and $\mathrm{CO}_{2}$ case studies, processes and perspectives. Ecological studies Series, Berlin: Springer; 2006;187:393-409.
5. Drigo B, Kowalchuk GA, Johannes AV. Climate change goes underground: effects of elevated atmospheric $\mathrm{CO}_{2}$ on microbial community structure and activities in the rhizosphere. Biology and Fertility Soils. 2008;44(5):667679.

6. $\mathrm{Hu} \mathrm{S}$, Chapin FS, Firestone MK, et al. Nitrogen limitation of microbial decomposition in a grassland under elevated $\mathrm{CO}_{2}$. Nature. 2001;409:188191.

7. Cheng WX, Johnson DW. Elevated $\mathrm{CO}_{2}$, rhizosphere processes, and soil organic matter decomposition. Plant and Soil. 1998;202(2):167-174

8. Benbi DK, Senapati N. Soil aggregation and carbon and nitrogen stabilization in relation to residue and manure application in ricewheat systems in northwest India. Nutrient Cycling in Agroecosystems. 2009;87:233-247. 